\title{
THE CELL CYCLE IN HEAT- AND SELECTION-SYNCHRONIZED SCHIZOSACCHAROMYCES POMBE
}

\author{
by \\ BIRTE KRAMHøFT \\ SUSANNE B. NISSEN \\ ERIK ZEUTHEN \\ The Biological Institute of the Carlsberg Foundation \\ 16 Tagensvej, DK-2200 Copenhagen N, Denmark
}

Key words: Schizosaccharomyces - Yeast - Cell cycle - Synchrony - Step enzymes

Schizosaccharomyces pombe, growing in a complex medium at $32^{\circ} \mathrm{C}$, was treated with 6 or 7 heat shocks $(30 \mathrm{~min}$, $\left.41^{\circ} \mathrm{C}\right)$ spaced one normal cell generation apart $\left(110 \mathrm{~min}, 32^{\circ} \mathrm{C}\right)$. This treatment results in synchronization of cell division, nuclear division, and DNA synthesis.

Between successive shocks increases in the activities of ATCase and OTCase are stepwise. However, steps are not seen at constant temperature, neither in free running heat synchronized, nor in selection synchronized cells. The enzyme steps we have studied therefore seem to be directly induced by the temperature shocks, and they are dissociable from the pattern of classic cell cycle events, which we find almost identical in heat and in selection synchronized cells.

\section{INTRODUCTION}

The fission yeast Schizosaccharomyces pombe can be synchronized by two fundamentally different procedures. Cells representing a narrow segment of the cell cycle can be selected from the original asynchronous culture and used as inoculum for a synchronous culture. Or the whole asynchronous culture can be induced to go through the cycle in phase by exposure to certain changes in growth conditions.

The two procedures can be compared either on basis of degrees of synchrony obtained, or by the amounts of material made available for study, or by the degree by which the cultures diverge from a chosen standard. In this work we use cultures which have been selection synchronized according to MITCHISON and VIN- 
CENT (16) as the standard normal with which to compare cells of the same species and strain synchronized by an induction method.

Several induction methods are available. Synchrony can be obtained by starvation as suggested by SANDO (17), by pulse treatment with deoxyadenosine as shown by MITCHISON and CREANOR (15), and by heat shocks as described by KRAMHøFT and ZEUTHEN $(8,9)$. It is the performance of the latter procedure which we seek information about in an attempt to meet statements that induction synchronized systems are seriously abnormal (13).

We have long held the view ourselves that the heat synchronized cultures produced by us are close to normal. The present work confirms this to our satisfaction.

\section{MATERIALS AND METHODS}

Cultures of the haploid strain $972 \mathrm{~h}^{-}$of Schizosaccharomyces pombe were originally obtained from Dr. JøRGEN FRIIS, University of Odense. Cells are kept at $4^{\circ} \mathrm{C}$ on dried silicagel. Stock cultures are produced in the following way: A few grains from a silica-gel culture are inoculated into liquid medium and incubated at $32^{\circ} \mathrm{C}$. When the cells are in exponential growth phase, a loop-full is transferred to test tubes containing slanted agar medium. These cultures are allowed to multiply at $32^{\circ} \mathrm{C}$ for $3-4$ days to become stationary, and are then stored at $4^{\circ} \mathrm{C}$. Agar cultures can be used for at least 2 months. Experimental cultures are produced from the slanted agar cultures in the following way: A loop of cells from a slanted agar culture is inoculated into $25-50$ $\mathrm{ml}$ of liquid medium and allowed to grow over night at room temperature. The next day this culture, now in exponential growth phase, is used as inoculum for the experimental culture.

The medium used in all experiments is complex. It contains $30 \mathrm{~g}$ glucose, $5 \mathrm{~g}$ Difco yeast extract and $2.1 \mathrm{~g} \mathrm{KH}_{2} \mathrm{PO}_{4}$ per 1 . The culture vessels are screw-capped or cotton-plugged Erlenmeyer flasks holding 100-500 ml of growth medium. The flasks are either suitably shaken, or the medium is stirred with a magnetic tefloncoated bar, equipped with an equatorial ridge. The ridge prevents grinding of the cells between the stirring bar and the glass wall.
Heat synchronized cultures are produced by immersing the culture in a cyclic water thermostat described in details elsewhere (9). Selection synchronized cultures are obtained according to the method of MITCHISON and VINCENT (16) avoiding any major temperature shifts during the procedure.

Cell multiplication is followed by counting samples drawn at 10-15 min interval in a Bürker-Türk counting chamber. Cells are counted as two when a "division furrow" becomes clearly visible, indicating that the cell plate has split into two layers each defining the rounded terminal wall of a daughter cell.

Nuclei are stained with Giemsa according to GaNESAN and Roberts ( 3 ) and GanEsan and SWAMinathan (4). Fractions of mono- and binucleate cells are calculated from counts using a Spencer microscope at $970 \times$ (oil immersion). Cells are binucleate by our definition from the moment when two nuclei can be seen to the moment when the new nuclei become separated by a continuous cell plate.

The proportion of cells with cell plates (the cell plate index) is calculated from counts of Giemsa stained preparations.

DNA is measured on samples of $1-2 \times 10^{8}$ cells using the diphenylamine method, modified as suggested by J. CREANOR and J. M. MitCHISON (personal communication). Cells are collected on a Whatman GF/A glass fiber filter and washed twice with distilled water. The filters are then frozen in centrifuge tubes. When convenient the cells are resuspended in $1.5 \mathrm{ml}$ ice cold $5 \%(\mathrm{v} / \mathrm{v})$ perchloric acid (PCA), spun down and washed once more with 5\% PCA. Following this the pellet is extracted in $0.3 \mathrm{ml} 5 \%$ PCA at $70^{\circ} \mathrm{C}$ for $20 \mathrm{~min}$ under very careful mixing and then centrifuged. $0.25 \mathrm{ml}$ of the supernatant is used for the assay and is mixed with 0.4 $\mathrm{ml}$ diphenylamine-reagent $(0.8 \mathrm{~g}$ recrystalized diphenylamine dissolved in $20 \mathrm{ml}$ glacial acetic acid and $0.05 \mathrm{ml}$ acetaldehyde solution, 16 $\mathrm{mg} / \mathrm{ml}$ ). This mixture is also added to a series of deoxyadenosine standards. The samples are then incubated over night at $32^{\circ} \mathrm{C}$. DNA is measured from the difference between readings at $595 \mathrm{~nm}$ and $720 \mathrm{~nm}$, using a standard curve and the equation: $\mu \mathrm{g}$ deoxyadenosine per $\mathrm{ml}=$ $\mu \mathrm{g}$ DNA per $\mathrm{ml} \times 2.605$. 
The activities of the enzymes aspartate transcarbamylase (ATCase) and ornithine transcarbamylase (OTCase) were estimated as described by BOSTOCK et al. (2) and GERHART and PARDEE (5) with modifications suggested by THORPE (20). Samples containing about $3 \times 10^{6}$ (ATCase) and $1 \times 10^{6}$ (OTCase) cells were drawn at intervals and placed in an icebath. They were then washed twice with ice cold distilled water and freezedried. The dry samples were suspended in $0.1 \mathrm{ml}$ borax buffer $(0.025 \mathrm{M}$, $\mathrm{pH} 9.5)$ and $0.1 \mathrm{ml}$ aspartic acid $(0.25 \mathrm{M}, \mathrm{pH} 9.5)$ or $0.1 \mathrm{ml}$ ornithine monochloride $(0.03 \mathrm{M}, \mathrm{pH}$ 9.5), respectively. The rest of the assay follows the procedure of Gerhart and PARDEE (5), except that we give the activity values as optical density per $\mathrm{ml}$ culture $(\mathrm{OD} / \mathrm{ml})$.

RNA was measured by a slight modification of the Schneider procedure as described by BOSTOCK (1) and protein was assessed according to the method of LowRY et al. (10). Dry weight was estimated on samples containing about $10^{8}$ cells. The cells were dried to constant weight on millipore filters $\left(105^{\circ} \mathrm{C}, 24 \mathrm{hrs}\right)$. Size distributions of cells at various time points were obtained in the following way: Samples of the populations were taken at intervals and photographed. The frames were then projected onto a screen, and cell dimensions were measured, so that plots of cell size distributions could be constructed.

\section{RESULTS}

The effect of heat shocks on cell division in cultures of Schizosaccharomyces pombe has been described in details previously (8). At that time the following synchronizing procedure was developed: Heat shocks $\left(41^{\circ} \mathrm{C}, 30 \mathrm{~min}\right)$ were applied with separating intervals equal to one generation time as measured in control cultures growing exponentially at the intershock temperature $\left(32^{\circ} \mathrm{C}\right)$. The generation time thus measured was $130 \mathrm{~min}$. However, in later work the quality of the synchrony was found less satisfactory. New measurements then disclosed that the generation time had changed to 110 $\min (107 \pm 5 \mathrm{~min}$ in 24 experiments). The cause of this has not been fully established, but we consider that it reflects change in the composi- tion of the yeast extract used, rather than change of the stock culture. This opinion is based on the observation that also a fresh sample of Dr. FRIIS' original stock now grows with a doubling time of $110 \mathrm{~min}$ in our medium.

\subsection{Heat shock synchrony}

Following these observations we have altered the shock program so that the interval between successive shocks is $110 \mathrm{~min}$. This is in agreement with our working hypothesis according to which good synchrony is only obtained when the interval between shocks equals the normal generation time of cultures growing undisturbed at the intershock temperature $(21,8)$. The other parameters of the synchronizing treatment are as before: $6-7$ shocks, each of 30 min at $41^{\circ} \mathrm{C}$, with $32^{\circ} \mathrm{C}$ between the shocks.

With this new program we obtain synchronous cultures fully comparable with the ones described before as seen in Table I. In this table we demonstrate the identical timings of the synchronous divisions in the original and in the modified system.

\subsubsection{Restricted heat synchrony}

The heading refers to synchrony maintained, in principle indefinitely, with the sequence of heat shocks which induced it. In the following we shall first report a sequence of biochemical and physiological events in the restricted system, $i$. e. essentially events occurring in the interval between successive shocks. Later we shall describe the free running system, or the events as they occur after the termination of the cyclic heat program.

Available information about the restricted system is summarized in Fig. 1. Each frame represents a typical experiment. Frame A shows cell multiplication. Following the sixth heat shock the number of cells in the culture stays constant for about $75 \mathrm{~min}$. A division burst occurs during the next $30-40$ min during which time the cell number doubles. The average mid point of the synchronous cell division ( $50 \%$ increase in cell number) is $95 \mathrm{~min}$ after the end of the shock (cf. Table I).

Frame B shows the synthesis of DNA (DNA per ml culture) in a heat shocked culture. There 
Table I

Time points of 1st and 2nd synchronous division in the original and in the modified heat synchronized system

\begin{tabular}{l|c|c}
\hline & \multicolumn{2}{c}{ Division, min after EH } \\
\hline & Original system & Modified system \\
a: Ist division: & $97 \pm 6(\mathrm{n}=25)$ & $94 \pm 7(\mathrm{n}=32)$ \\
& & $186 \pm 12(\mathrm{n}=8)$ \\
\hline b: 2nd division: & $187 \pm 6(\mathrm{n}=6)$ & \\
\hline $\begin{array}{l}\text { Free running } \\
\text { generation } \\
\text { time (b-a) }\end{array}$ & $90 \mathrm{~min}$ & $92 \mathrm{~min}$ \\
\hline
\end{tabular}

The interval from the end of the heat treatment (EH) to the time point of $50 \%$ increase in cell numbers at first and second synchronous division was determined in several experiments. The time points are given as mean \pm S.D.

The interval between shocks is $130 \mathrm{~min}$ in the original system, and $110 \mathrm{~min}$ in the modified system used in this paper. The temperature between shocks is $32^{\circ} \mathrm{C}$ and the heat shocks $30 \mathrm{~min}$ at $41^{\circ} \mathrm{C}$ in both systems.

is no net DNA synthesis until about $60 \mathrm{~min}$ after the shock ( $58 \pm 13 \mathrm{~min}$ in 4 experiments), then the amount of DNA doubles before the onset of the next shock. The average time point of mid $S$ ( $50 \%$ increase in DNA) is 80 min after the end of the shock $(81 \pm 10 \mathrm{~min}$ in 4 experiments).

The synchrony can also be monitored by measuring the time points of nuclear division and of cell plate formation. This is done by following changes with time in the proportion of cells with two nuclei - but no continuous cell plate - and the proportion of cells with cell plates, respectively. The time point of cell plate formation indicates the time when the two daughter cells become physiologically separated - which slightly precedes the physical separation of the daughter cells. Frame C shows the result of one such experiment. Peaks of binucleate cells and of cells with cell plates appear about 35 and $15 \mathrm{~min}$ before the division, respectively.

The enzymes aspartate transcarbamylase (ATCase) and ornithine transcarbamylase (OTCase) are described as step enzymes in selection synchronized cultures of Schizosaccharomyces $(2,12)$. Also in heat treated cultures the activities of these enzymes increase discon- tinuously. This is seen in Frame D which shows the activity of ATCase and OTCase as functions of time after seven shocks. With ATCase no net increase in activity is observed before about $45 \mathrm{~min}$ after the shock $(44 \pm 12$ $\min$ in 9 experiments). Within the next hour the activity of the enzyme approximately doubles, with $50 \%$ increase at about $75 \mathrm{~min}$ after the shock ( $74 \pm 16 \mathrm{~min}$ in 6 experiments). The doubling is terminated before the onset of the next shock.

The activity of OTCase begins to increase earlier after the shock, at about $10 \mathrm{~min}$ after $\mathrm{EH}$ $(7 \pm 10 \mathrm{~min}$ in 6 experiments). The activity then approximately doubles, the time point of $50 \%$ increase being about $55 \mathrm{~min}$ after the end of the shock ( $54 \pm 9 \mathrm{~min}$ in 6 experiments). Also here the doubling is finished before the next shock.

In normal cells RNA and bulk protein synthesis occur throughout the cycle at more or less smoothly increasing rates (19). The same holds true in the heat synchronized system, except that synthesis is interrupted for some time by each shock. This is seen in Fig. 1, frames $E$ and F.

\subsubsection{Free running heat synchrony}

When the heat treatment is discontinued after a number of cycles and the cultures are allowed to develop freely, the results shown in Fig. 2 are obtained. Frame A shows cells per $\mathrm{ml}$ as a function of time after 7 shocks. It is seen that the synchrony persists for at least two generations, each division burst resulting in a doubling in cell number. The two bursts of synchronous divisions are separated by $90 \mathrm{~min}$. (See also Table I.)

Figure 1. Changes in various cell parameters through the synchronized cell cycle induced with 6 or 7 heat shocks. Restricted synchrony: changes from heat shock through next heat shock. (A) cell number per ml culture. (B) DNA content per ml culture. (C) percentage of the culture with binucleate cells (filled circles) and with cell plates (open circles). (D) activity of OTCase (filled circles) and ATCase (open circles) in relative units (OD per $\mathrm{ml}$ culture). (E) RNA content per ml culture, and $(F)$ protein content per $\mathrm{ml}$ culture. The arrow indicates the time point of $50 \%$ increase in cell number in the respective experiments. The blocks symbolize the heat shock program. 


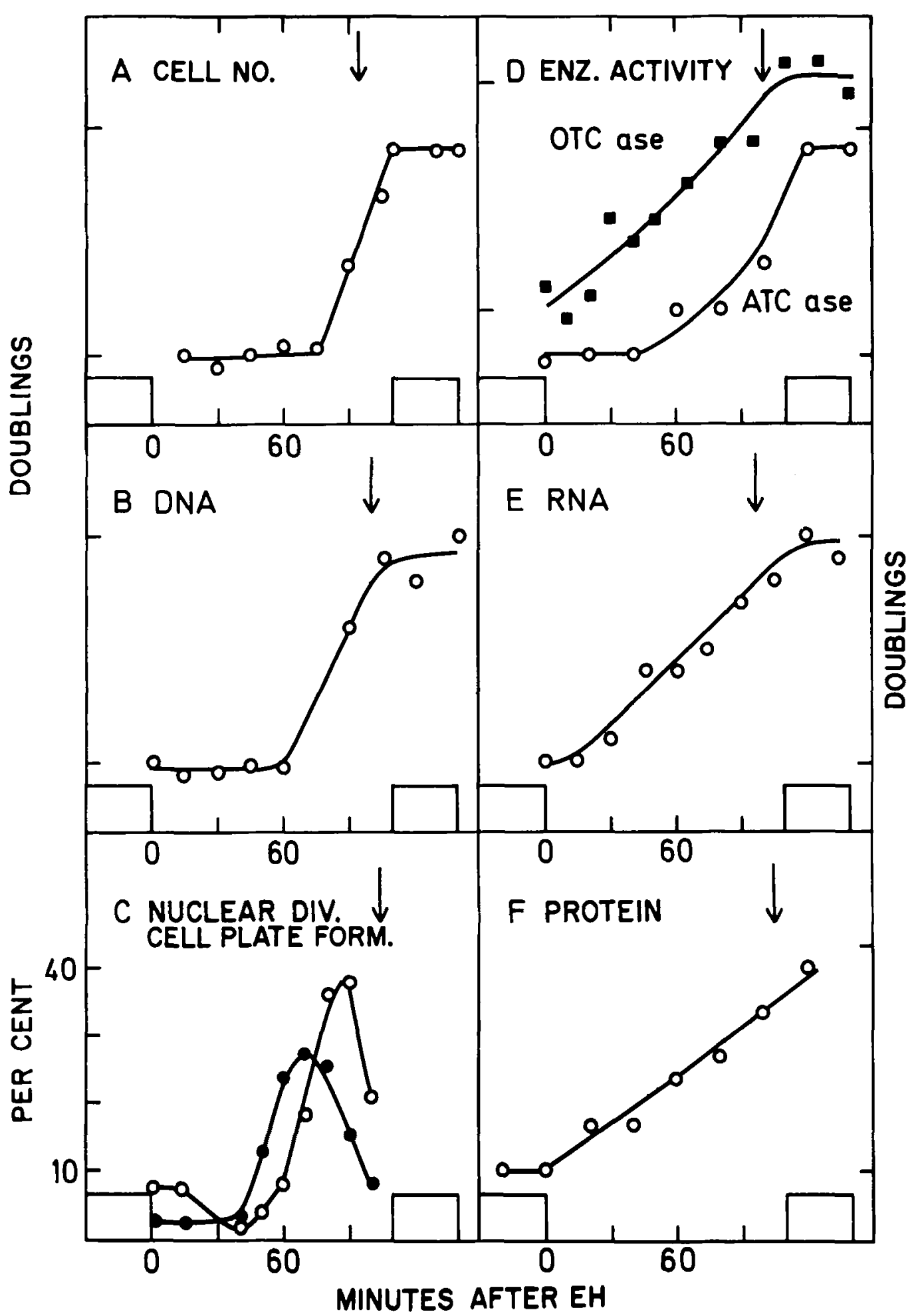


DNA per ml culture as a function of time is shown in frame B. The S-period following the 6th or 7th shock (see also Fig. 1, frame B) results in a doubling in DNA. Then comes a period without DNA synthesis, and just before the second division there is a new doubling in the amount of DNA in the culture. The time points of mid-S ( $50 \%$ increase in DNA) are at 80 and $170 \mathrm{~min}$ after the end of the heat treatment, respectively. In other words, mid-S precedes mid-division by about $15 \mathrm{~min}$ (cf. Table I).

Table II compares amounts of DNA in selection synchronized and in heat synchronized cells at comparable points in the cycle, i.e. after a division and prior to the S-period. Apparently, there is no demonstrable difference in the

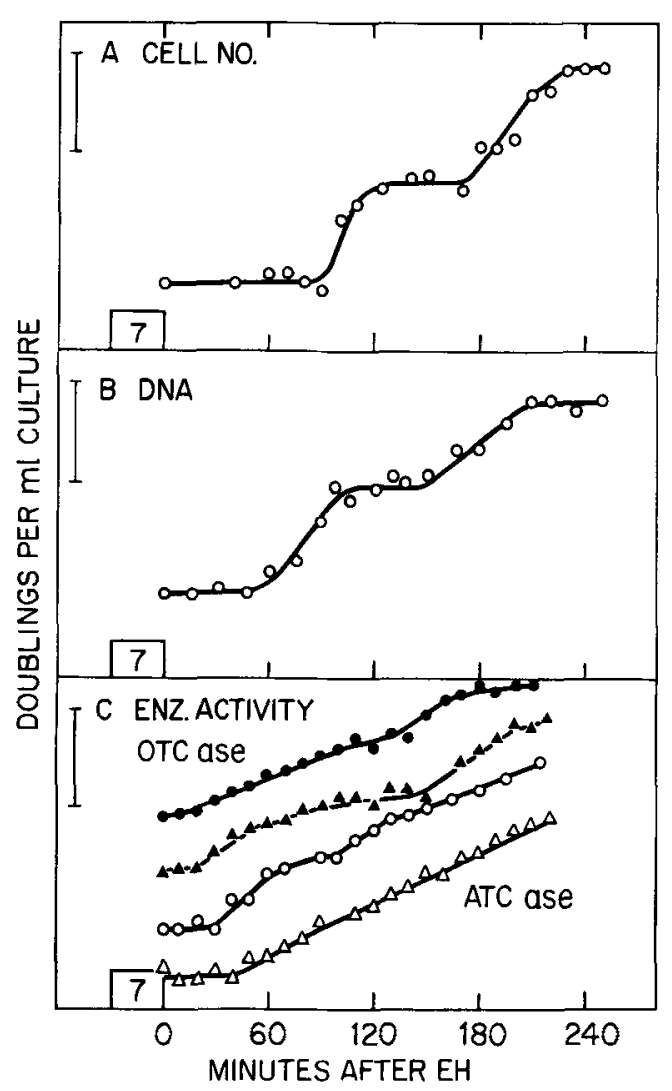

Figure 2. Variation with time in free running heat synchronized cultures of: (A) cell number per ml culture, (B) DNA content per ml culture, and (C) enzyme activities (OD per ml culture). In (C) the results of two typical experiments with OTCase (filled symbols) and ATCase (open symbols) are shown. The vertical bar on the logarithmic ordinate equals a doubling. The squares symbolize the final heat shock. amount of DNA per cell in the two synchronous systems.

Frame $\mathrm{C}$ shows increases with time after the final shock in the activities per ml culture of ATCase and OTCase. (The cell-free medium was tested for activity and had none.) As shown earlier in Fig. 1, frame D, ATCase activity increases after an initial lag of about $45 \mathrm{~min}$. However, when the next restricting heat shock is omitted, as in this case, the increase is continuous and more or less log-linear with a doubling time of $110 \mathrm{~min}$, the duration of a normal cell generation.

As shown also in Fig. 1, frame D, OTCase begins to increase sooner after the heat shock than is seen with ATCase. The increase is more or less continuous except that poorly reproducible plateaus tend to appear around the time when a next heat shock would have come, had the shock program been continued.

The temporary block for protein- and RNA synthesis by the heat shocks, characteristic of the restricted heat synchronized system (Fig. 1, frame F), are absent in the free running system. In this case synthesis procedes log linearly with a doubling time which nearly equals the doubling time $(110 \mathrm{~min})$ for cell numbers in exponentially multiplying populations (not shown).

\subsection{Selection synchrony}

In order to be able to compare induced synchrony with a generally accepted standard we have selection synchronized our strain a.m. MITCHISON and VINCENT (16), using the complex medium. We obtained the results shown in Fig. 3. Frames $A$ and $B$ show cell number per $\mathrm{ml}$ and DNA content per $\mathrm{ml}$ as functions of time after inoculation, respectively. In separate experiments time points of nuclear division (ND) and of cell plate formation (CP) were determined. In this system nuclear division, cell plate formation, and DNA synthesis precede cell division by 35,15 and $5 \mathrm{~min}$, respectively. These data agree well with our observations on heat synchronized cells and with observations on cells which are selection synchronized in a chemically defined medium $(2,1,14)$.

Frame $\mathrm{C}$ shows enzyme activities as functions of time after inoculation of a synchronous 


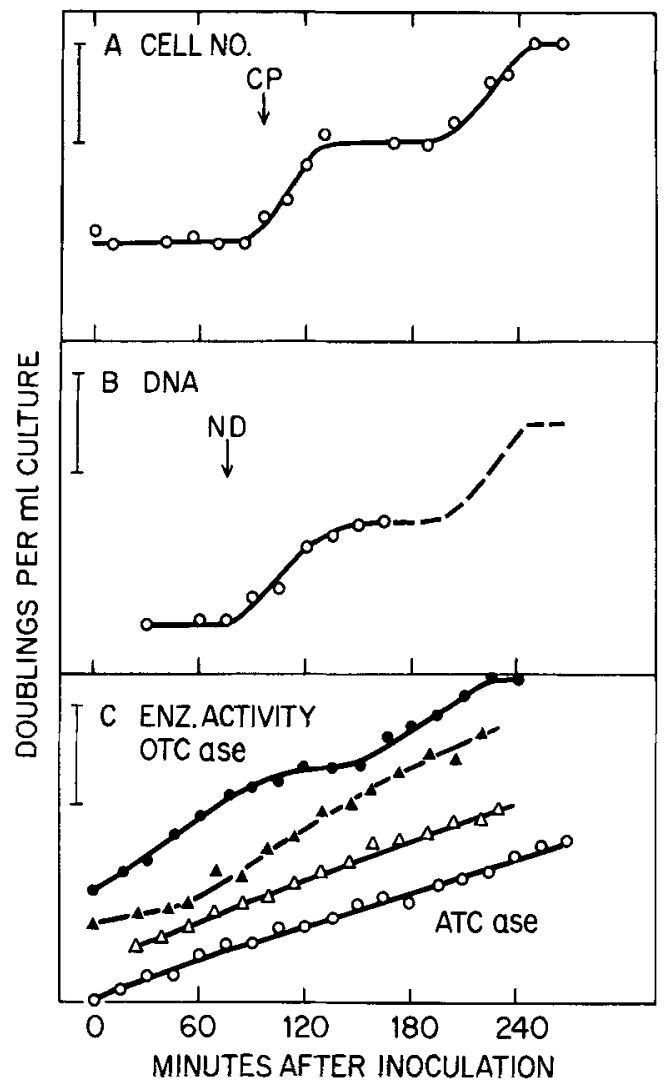

Figure 3. Variations with time in selection synchronized cultures of: (A) cell number per $\mathrm{ml}$, (B) DNA content per $\mathrm{ml}$, and (C) enzyme activity per $\mathrm{ml}$. In (C) the results of two typical experiments with OTCase (filled symbols) and ATCase (open symbols) are shown. The cultures were inoculated with small cells selected $a . m$. Mitchison and Vincent at time zero.

culture. Apart from the absence of the initial lag in ATCase increase (cf. Fig. 1 and 2) we see little difference between these curves and the ones shown in Fig. 2 (free-running heat synchrony). Wavy patterns can sometimes be seen, but they are not reproducible. Thus the statement made for free running heat synchronized cells is valid also for selection synchronized cultures: the activities of ATCase and OTCase per ml culture increase continuously with time and with a doubling time equal to the generation time of exponentially growing cells. Consequently, enzyme activity patterns observed by us in both heat synchronized and selection synchronized cultures differ from the stepwise mode of increase reported by MITCHISON and collaborators for cultures which are selection synchronized in a chemically defined medium $(2,12)$.

The synthesis of bulk protein and RNA has also been followed in these cultures. The pattern (not shown) suggests an exponential increase with time of these macromolecules.

\subsection{Cell cycle maps}

The cell cycle maps shown in Fig. 4 are constructed on the basis of information gained with the two synchronous systems, both studied in the complex medium. The upper map shows cells synchronized by selection, the lower one cells synchronized by heat treatment. In both cases the time points of cell cycle events are related to the time of the forthcoming rather than to that of the preceding division, and the time scale is divided into fractional units, the duration of the cell cycle representing one unit. In these terms the timing of nuclear division, DNA synthesis and cell plate formation is similar in both systems. It is, however, seen that the first part of the cycle is extended when synchrony is maintained by repeated heat shocks. Upon change from restricted to free running synchrony this phase shortens relattvely to what is seen in selection synchronized cells. Selection synchronized cells differ from heat synchronized cells with respect to patterns of enzyme activities; the former shows continuous and smoothly increasing enzyme synthesis, the latter shows interruptions in synthesis related to the heat shock.

\subsection{Cell size}

Schizosaccharomyces pombe is said to grow only in length (11). The size distributions of cell length at various time points should thus reveal to which extent heat shocks phase cell growth, as distinct from cell division and DNA synthesis. If cell growth is optimally phased by the heat treatment, the spread of cell lenght in cells having a cell plate should be similar in heat synchronized as well as in selection synchronized and asynchronously dividing cells. In Fig. 5 we show histograms of the distributions of the lengths of cells showing cell plates in A: an exponentially multiplying culture, and $\mathrm{B}$ : a heat synchronized culture. It is clearly seen that the 


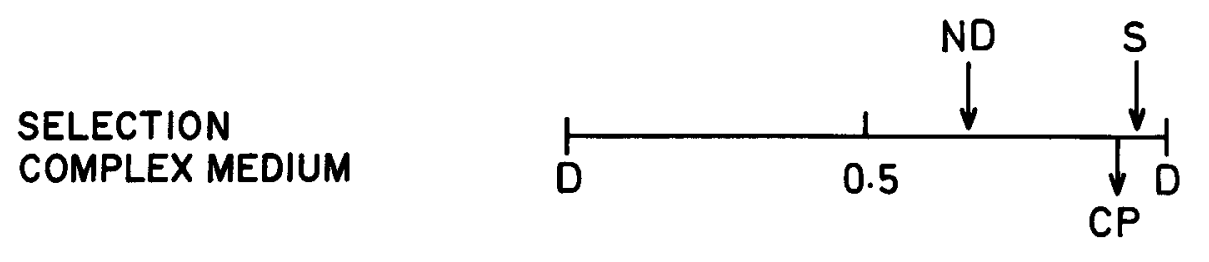

\section{HEAT SHOCK COMPLEX MEDIUM}

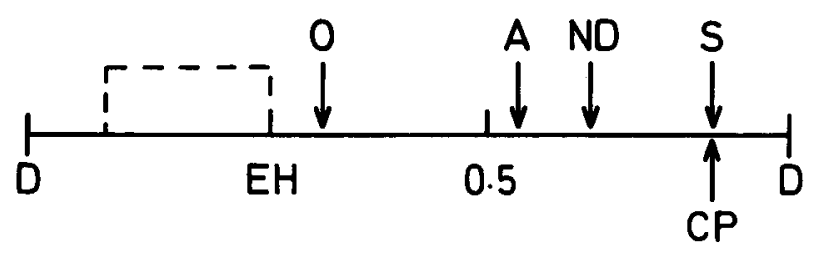

Figure 4. Cell cycle maps. Time points of the occurrence of nuclear division (ND), DNA synthesis (S), cell plate formation (CP) and the initiation of increases in activities of OTCase $(O)$ and ATCase (A) are plotted on a fractional cell cycle time scale, sectioning back from a division. ND and CP represent peak values, $S$ and D values of $50 \%$ increase in DNA content and cell number, respectively. Time points when enzyme activities begin to increase after the heat shock are indicated by $O$ (OTCase) and $A$

distribution of cell lengths is almost identical in the two cultures. We conclude therefore that heat shocks phase cell growth.

However, heat synchronized cells are somewhat larger than logarithmic cells. The average length of heat synchronized cells with cell plates is $14.1 \pm 1.2 \mu(\mathrm{n}=32)$ compared to 14.9 $\pm 0.9 \mu(n=27)$ in log cells, thus the two types of cells have almost same length, but the heat synchronized cells are thicker than normal cells. The average width of heat synchronized cells is $3.9 \pm 0.2 \mu(\mathrm{n}=72)$ compared to $3.3 \pm 0.2 \mu(\mathrm{n}=$ 80 ) in logarithmic cells. The average volume of the two types of dividing cells can be calculated from the equation of Mitchison (11). The figures are shown in Table II, and it appears that the average volume of heat synchronized cells exceeds that of log phase cells by about $30 \%$. This oversize is not reflected in an in-
(ATCase), respectively. EH is the end of a heat shock, the placement and duration of which is shown with a square block on the axis.

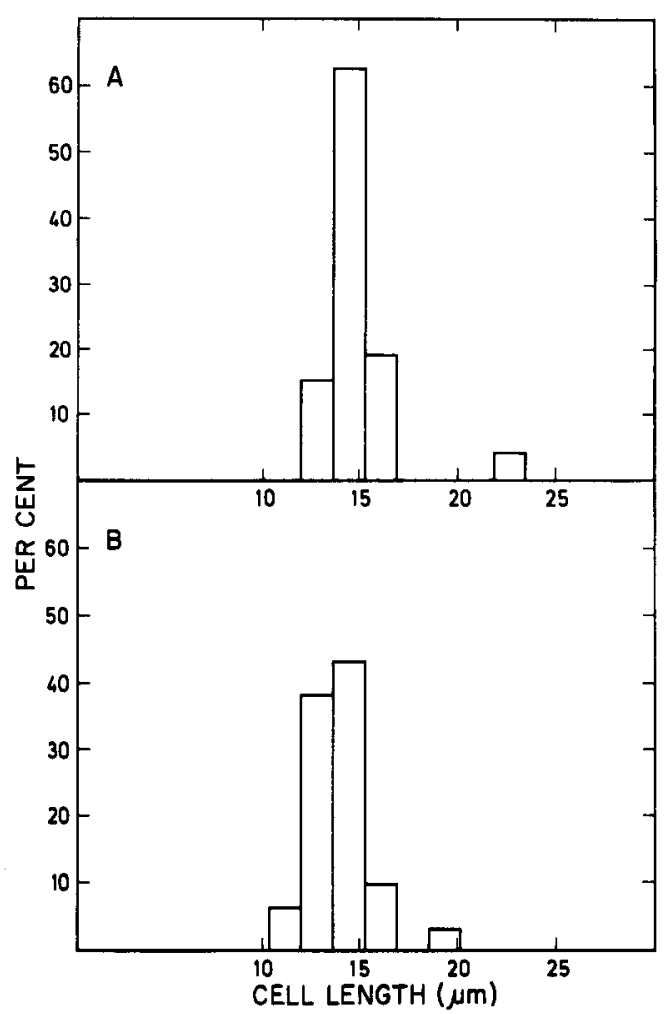

Figure 5. Histograms showing distributions of cell lengths (A) in exponentially growing cells having a cell plate and (B), in heat synchronized cells with cell plates. 
Table II

Cellular parameters in Schizosaccharomyces pombe.

A Heat synchronized:

\begin{tabular}{c|c|c|c|c}
\hline DNA & RNA & Protein & Dry w. & Vol. \\
\hline 0.042 & 6.8 & 22 & 52.3 & \\
0.033 & 7.2 & 29 & 47.1 & \\
0.042 & 6.3 & 24 & 45.8 & \\
0.037 & 6.2 & 33 & 53.5 & \\
0.036 & & 21 & 47.1 & $153^{*}$ \\
\hline
\end{tabular}

B Selection synchronized:

\begin{tabular}{c|c|c|c|c}
\hline DNA & RNA & Protein & Dry w. & Vol. \\
\hline 0.036 & 5.0 & 17 & 35.9 & \\
0.036 & 4.6 & 13 & 33.1 \\
$0.036^{* *}$ & & 18 & 37.1 & \\
& & & 34.7 & \\
& & & 35.5 & \\
Mean: 0.036 & 4.8 & 16 & 35.3 & $118^{*}$ \\
S.D. \pm 0.000 & 0.3 & 3 & 1.5 & \\
\hline
\end{tabular}

Legend: $\quad$ DNA, RNA, protein and dry weight are in $\mathrm{pg} /$ cell; volume is in $\mu^{3} / \mathrm{cell}$. DNA are $2 \mathrm{C}$ values (haploid) (1). RNA and protein are measured midway through the synchronized division (arrows in Fig. 1). Dry weight was determined on samples removed at the time of the cell plate maximum. Only volume measurements were made with single cells, always having a cell plate.

Notes: $\quad$ *) Calculated from average length and width, (section 3.4), using an equation from Mitchison (11).

**) Value from Mitchison and Creanor (14).

creased content of DNA in heat synchronized cells, but in a higher content of protein and RNA, and in increased dry weight. This is shown in Table II.

\section{DISCUSSION}

In this paper we compare the heat shock synchronized Schizosaccharomyces pombe system of KRAMHøFT and ZEUTHEN $(8,9)$ with the selection synchronized system of MiTCHISON and VINCENT, and BosTOCK et al. (16, 2), keeping parameters constant other than those directly related to the procedure by which synchrony is obtained.
Populations of cells synchronized either way are similar with respect to important properties. Thus cells in the same phase of the cycle show similar size distribution whether they are members of an exponentially multiplying or of a synchronous population established by use of heat shocks. The comparison presented in Fig. 5 refers to cells possessing a cell plate and thus making ready to divide. It is also important that heat synchronized cells carry normal amounts of DNA as shown in Table II. Thus there is no indication that heat shocks dissociate a growth cycle from a division DNA cycle - such as size distributions indicate occurs when deoxyadenosine rather than heat shocks is used for 
synchrony induction (18). Studies with Tetrahymena have shown that heat shocks can create a different dissociation, $i$. e. separate division from DNA synthesis $(6,7)$, but it has also been demonstrated that this can be fully remedied if the heat shocks are separated by a normal generation time (21), the principle adopted in this study.

The heat shock program synchronizes cell division and other cyclic events, and once the synchrony has been obtained, the cycle is laid out almost normally in each interval between shocks. However, heat shocks also induce capacity for accelerated division, clearly demonstrated when cell divisions are allowed to run freely after the heat shocks. This is seen both when cells are heat synchronized in the complex medium and in a defined medium (unpubl.). Thus the time from division to division in the free running systems is about $90 \mathrm{~min}$, apparently regardless of growth medium used and of exponential growth rates in these media (110 and $140 \mathrm{~min}$, respectively). Consequently, the doubling time for cell numbers is anything from 20 to $50 \mathrm{~min}$ longer in exponentially multiplying than in synchronized cells, and in the latter this time is reduced to what seems to be a standard. This is obtained by reduction of the part of the cell cycle which seems empty on the cell cycle maps (Fig. 4), apart from the enzyme steps which are dubious to us, see later. Apparently, the synchronized free running cells are less limited with respect to capacity to divide than are normal cells. This may reflect that heat synchronized cells deal more successfully than untreated cells with environmental growth factors, or simply that they are slightly oversized, as shown in Table II. The heat synchronized cells are not demonstrably elongated, but they are slightly thicker than exponentially multiplying cells in identical phases of the cycle. The size of the genome being unaffected this accounts for a harmonious, about $30 \%$, increase in volume, protein, RNA and dry weight of these cells.

The two enzymes ATCase and OTCase have been studied in selection synchronized cultures of $S$. pombe (2). In such cultures growing in a synthetic medium the enzyme activity increases in steps, one per cycle much resembling what we have indicated in our Fig. 1. This figure shows that increases in these two enzyme activities suffer temporary cessation by each heat shock, and that after the shock new increase in OTCase precedes increase in ATCase activity. The former enzyme activity rather closely parallels general protein synthesis, but the latter enzyme lags behind after each new shock. Consequently, by MiTCHISON's criteria $(2,12)$ the two enzymes might be described as step enzymes in restricted heat synchronized cells. However, steps are absent in both free running heat synchronized cells and in our selection synchronized cells, and therefore we consider steps in these enzyme activities as environmentally induced and dissociable from the classic cell cycle events on which we have based this report.

\section{REFERENCES}

1. Bostock, C. J, DNA synthesis in the fission yeast Schizosaccharomyces pombe. Exptl. Cell Res. 60: 16-24 (1970)

2. Bostock, C. J., Donachie, W. S., Masters, M. \& Mitchison, J. M. Synthesis of enzymes and DNA in synchronous cultures of Schizosaccharomyces pombe. Nature 210: 808-810 (1966)

3. Ganesan, A. T. \& Roberts, C. Observations on the nuclear cytology of Lipomyces lipofer. Compt. Rend. Trav. Lab. Carlsberg 31: 175-181 (1959)

4. Ganesan, A. T. \& Swaminathan, M. S. Staining the nucleus in yeasts. Stain. Techn. 33: 115-123 (1958)

5. Gerhart, J. C. \& Pardee, A. B. The enzymology of control by feedback inhibition. J. Biol. Chem. 237: $891-896$ (1962)

6. HJelm, K. K. \& ZeUThen, E. Synchronous DNA synthesis following heat-synchronized cell division in Tetrahymena. Exptl. Cell Res. 48: 231-232 (1967)

7. HJELM, K. K. \& ZeUTheN, E. Synchronous DNAsynthesis induced by synchronous cell division in Tetrahymena. Compt. Rend. Trav. Lab. Carlsberg 36: 127-160(1967)

8. KRamhøFT, B. \& ZeUthen, E. Synchronization of cell divisions in the fission yeast, Schizosaccharomyces pombe, using heat shocks. Compt. Rend. Trav. Lab. Carlsberg 38: 351-368 (1971)

9. KRAMHøFT, B \& ZEUTHEN, E. Synchronization of the fission yeast Schizosaccharomyces pombe using heat shocks, in: Methods in Cell Biology (Prescott, D. M. ed.), vol. 12, pp. 373-380, Academic Press, London and New York. (1975) 
10. Lowry, O. H., Rosebrough, N. J., FArR, A. L. \& Randall, R. J. Protein measurements with the folin phenol reagent. J. Biol. Chem. 193: 265-275 (1951)

11. Mitchison, J. M. The growth of single cells $\mathbf{I}$. Schizosaccharomyces pombe. Exptl. Cell Res. 13: 244-262 (1957)

12. Mitchison, J. M. The Biology of the Cell Cycle, pp. 159-181, Cambridge University Press. (1971)

13. Mitchison, J. M. \& Carter, B. L. A. Cell cycle analysis, in: Methods in Cell Biology (Prescott, D. M. èd.), vol. 11, pp. 201-219, Academic Press, London and New York (1975)

14. Mitchison, J. M. \& Creanor, J. Further measurements of DNA synthesis and enzyme potential during cell cycle of fission yeast Schizosaccharomyces pombe. Exptl. Cell Res. 69: 244-247 (1971)

15. Mitchison, J. M. \& Creanor, J. Induction synchrony in the fission yeast Schizosaccharomyces pombe. Exptl. Cell Res. 67: 368-374 (1971)
16. Mitchison, J. M. \& VincENT, W. S. Preparation of synchronous cell cultures by sedimentation. Nature 205: 987-989 (1965)

17. SANDO, N. Biochemical studies on the synchronized culture of Schizosaccharomyces pombe. J. Gen. Appl. Microbiol. 9: 233-241 (1963)

18. Sissons, C. H., Mitchison, J. M. \& Creanor, J. Enzyme synthesis and potential during induction synchrony in the fission yeast Schizosaccharomyces pombe. Exptl. Cell Res. 82: 63-72 (1973)

19. Stebbing, N. Growth and changes in pool and macromolecular components of Schizosaccharomyces pombe during the cell cycle. J. Cell Sci. 9: $701-717$ (1971)

20. Thorpe, S. M. Effects of elevated temperature shocks on asynchronous and synchronous populations of the fission yeast Schizosaccharomyces pombe. Candidate Thesis, University of Copenhagen. (1974)

21. Zeuthen, E. Synchrony in Tetrahymena by heat shocks spaced a normal cell generation apart. Exptl. Cell Res. 68: 49-60 (1971) 